ISSN: 1110-5623 (Print) - 2090-0570 (Online)

\title{
PRODUCTIVE PERFORMANCE IN LOCAL CHICKEN AFTER FIVE GENERATIONS OF CROSSING AND SELECTION FOR HIGH LIVE BODY WEIGHT
} Farid S. Nassar

Dep. of Anim. Prod., Fac. of Agric.e, Cairo Uni., Giza 12613, Egypt

Corresponding author: Farid Saber Nassar; Email: Fidsaber_nassar@agr.cu.edu.eg Abbreviated title: Selection and productive performance in local chicken

$$
\text { Received: 09/08/2017 Accepted: 23/08/2017 }
$$

\begin{abstract}
This study was conducted to evaluate the effect of selection on the productive performance of local chicken line, Giza M-2 line, after 5 generations of selection for increasing 6-week live body weight (LBW). The performance of Giza M-2 and Random Bred Control (RBC) lines; LBW, LBW at sexual maturity (BWSM), egg number $(\mathrm{EN})$, egg weight $(\mathrm{EW})$, and first egg weight $(\mathrm{FEW})$ were evaluated at the $3^{\text {rd }}$ (G3), $4^{\text {th }}(\mathrm{G} 4)$, and $5^{\text {th }}(\mathrm{G} 5)$ generations. The Random Bred Control line (RBC) was used as a control group. The results could be summarized as follow: There was significant improvement in 6-week LBW for Giza M-2 line from one generation to the next. The difference between Giza M-2 line and RBC line was $358 \mathrm{~g}$ after five generations of selection for increasing 6-week LBW. Also, females of Giza M-2 line had significantly higher BMSW, EN, EW, and FEW with comparison to the RBC line for all generations. In conclusion, there was positive response in LBW and egg productive performance in Giza M-2 line associated with our breeding program. Also, selection in Giza M-2 line may had large impact on frequency of genes controlling economically important traits, such as LBW and reproduction. In Giza M-2 line, future generations, to achieve proper meat production, we will focus on genetic selection of traits relevant to modern broiler breeding.
\end{abstract}

Key Words: Broiler breeders, Body weight, Egg production, Selection, Sexual maturity. 


\section{INTRODUCTION}

The consumption of poultry meat around the world is constantly increasing by the universal demand, because of its nutritional and dietary properties, diversity and ease of preparation, and low price (Petracci and Cavani, 2012). In addition, universal poultry meat consumption and production are expected to increase by 1.8 $\%$ per year from 2007 to 2050 (FAO, 2015). Thus, enhancing production levels and produce birds with higher feed efficiency and growth rates will be an efficient tools to meet this increased in demand poultry meat demand. Intensive genetic selection has been the method to improve economically traits in poultry production (Alnahhas et al., 2016).

Stainton et al. (2017) stated that the development of broiler chickens over the last 70 years has been accompanied by large phenotypic changes In addition, poultry breeding companies have used quantitative selection practices to improve productive performance the poultry industry today (Hunton, 2006). In broiler breeding program, mainline pedigree broiler populations, categorized into male and female lines, undergo continuous genetic selection to achieve higher improvements in the major economic traits. For the male lines, these traits include body weight, body conformation, growth rate, fitness, edible meat yield, and feed conversion ratio. These major traits were improved by positive selection. That is regenerated from the best families while the minor traits, such as fertility, hatchability, and livability, are impacted by eliminating the few worst families (Pollock, 1999; Muir et al., 2008).

In modern poultry industry, the live body weight (LBW) and carcass traits are under intensive selection for more than half a century which are very important economic traits in broiler breeding programs (Baéza et al., 2012). In addition, Egg production is also an important economic trait for broiler breeder lines (Luo et al., 2007). Moreover, Commercial broiler breeds are derived from crosses and highly selected of various strains at the primary breeder level (Wolanski et al., 2006). Thus, a balance of features related to growth and reproduction must be considered when developing and maintaining commercial strains of broilers from great-grandparent lines which can influence the genetic makeup of the birds (Decuypere et al., 2003).

Also, Selection for increased LBW is known to be negatively associated with the onset of sexual maturity, fertility, and egg production (Siegel and Dunnington, 1985). However, broiler breeder lines growth rate and egg production have moderate heritability values and will show more response to selection (Chambers, 1990).

Selection for increased 6-week LBW was carried on Giza M-2 line for five generations. The objectives of the current study were to evaluate the effect of selection on the productive performance of local chicken line, Giza M-2, during generation $3^{\text {rd }}(\mathrm{G} 3), 4^{\text {th }}(\mathrm{G} 4)$, and $5^{\text {th }}(\mathrm{G} 5)$ generation of selection.

\section{MATERIALS AND METHODS 1. History of Giza M-2 line as a broiler breeder male line}

A selection improvement program was started at the Poultry Farm, Animal Production Department, Faculty of Agriculture, Cairo University, Giza, Egypt, to develop Giza M-2 line as a local broiler male line. Fifteen rosters from Pureline grandparent male line males were crossed with 150 females from the native Egyptian chickens breed, Native White 
Broiler breeders, Body weight, Egg production, Selection, Sexual maturity.

Baladi, to produce the base generation of the Giza M-2 line.

The produced cross was reared until maturity and housed in individual cages. One hundred males and One hundred females were selected at random from the base generation and were mated at a ratio of one male to every 10 females. This was done by using artificial insemination to obtain pedigreed fertile eggs. Fertile eggs were collected for 15 days and hatched to produce the $F_{1}$ selected Giza M-2 line. Also, fertile eggs were collected again for 15 days, from the Random Bred Control line, RBC line. This line was formed by crossing Arbor Acres (AA) grandparent female line males, with the native Egyptian White Baladi females reared with random mating without any breeding program for more than 13 generation as Random Bred Control line, RBC line, for chicken lines associated with meat production (Nassar et al., 2012). All produced chicks were wing banded to keep their pedigree. Both lines were reproduced by using an out breeding program, with no full or half sibs mating allowed. For all the selected generations of Giza M-2 line, phenotypic selection was used to identify the best broiler breeders to produce the next generation. The highest 6-week LBW males and females were selected as parents for the next generation in Giza M-2 line.

Giza M-2 as local chicken line is the first Egyptian male line specialized in meat production. Giza M-2 line has a round, massive body shape. The tail feathers and saddle region in the males are rich. The females lay white to creamy shell color eggs. Both males and females have mostly white feathers, red single combs with long wattles, red earlobe color, yellow skin, and yellow shank colors.

\section{Experimental populations and management}

In this study, Giza M-2 line selected males and females, from the second selected generation, were mated to produce the third generation (G3). Also, males and females from the second generation RBC line were mated to produce the $\mathrm{RBC}$ chicks. Giza M-2 and the RBC pedigreed chicks' were sexed at hatch, using the vent method. All chicks were reared intermingled, 10 birds $/ \mathrm{m}^{2}$, in an open house, deep litter system, until 18 weeks of age. Pullets were then moved to individual laying cages at 18 weeks of age until 36 weeks of age. This procedure was repeated for all the successive generations of selection in generations four (G4), and five (G5) presented in our study.

Birds were provided with a commercial broiler starter $(23 \% \mathrm{CP}$ and $3,050 \mathrm{kcal}$ $\mathrm{ME} / \mathrm{kg}$ ) and a broiler grower (21\% CP and $3,100 \mathrm{kcal} \mathrm{ME} / \mathrm{kg}$ ) diets from 1 to 14 days and from 15 days to 6 weeks of age respectively. Also, birds were provided with a commercial pullet grower $(16.5 \%$ $\mathrm{CP}$ and $2780 \mathrm{ME} / \mathrm{kg}$ ) and a commercial breeder production $(17 \% \mathrm{CP}$ and 2800 $\mathrm{ME} / \mathrm{kg}$ ) diets from 7 to 19 weeks and from 20 to 36 weeks of age respectively.

Water and feed were provided ad libitum from hatch until 6 weeks of age, thereafter, feed allocations were only used to maintain target body weight profiles from 6 until 18 weeks of age. Restricted birds received approximately $110 \mathrm{~g} / \mathrm{d}$ from 6 to 18 weeks of age and received approximately $160 \mathrm{~g} / \mathrm{d}$ from 18 to 36 weeks of age. The photoperiod was 24L:0D for the first 6 weeks and 16L: 8D from 18 to 36 weeks of age.

Chicks were vaccinated against Newcastle disease at 7 days (eye drop, Hitchner, Nobilis ${ }^{\circledR}$ ), at 10 days (S/C injection with Newcastle inactivated vaccine, Nobilis $\left.{ }^{\circledR}\right)$, 
Farid S. Nassar

and at 21 days (eye drop, La Sota strain, Nobilis ${ }^{\circledR}$ ). Chicks were also vaccinated against infectious bursal disease at 14 and 24 days (eye drop) using Gumboro $\mathrm{D}_{78}$ strain $\left(\right.$ Nobilis $\left.^{\circledR}\right)$. In February 2006, there was an outbreak of the virulent avian influenza virus $\left(\mathrm{H}_{5} \mathrm{~N}_{1}\right)$ in Egypt (Abdou et al., 2008). Thus, the baby chicks from that time on were vaccinated against avian influenza virus by using (S/C) injection of $\mathrm{H}_{5} \mathrm{~N}_{2}$ inactivated vaccine at one week of age. The inactivated $\mathrm{H}_{5} \mathrm{~N}_{2}$ vaccine was injected subcutaneously in the lower back of the neck region. Moreover, vaccination with ND (La Sota strain, Nobilis ${ }^{\circledR}$ ) was repeated after 25 days of injection by intramuscular injection methods. Vaccination with $\mathrm{H}_{5} \mathrm{~N}_{2}$ was also repeated every 4 months from the previous injection. At 60 days of age, birds were vaccinated against Fowl Pox (wing web, Fowl Pox vaccine, Nobilis ${ }^{\circledR}$ ).

\section{Experimental measurements}

In all generations, live body weights (LBW) at hatch, 14, 28, 42 days were obtained individually by using a digital scale from the Giza M-2 and the RBC lines. Also, age at sexual maturity (ASM), body weight at sexual maturity (BWSM), average egg weight (EW), egg numbers (EN), and first egg weight (FEW) were recorded for each female in Giza M-2 and the RBC lines during the first 36 weeks of age.

\section{Statistical analysis}

Data were analyzed as a two-way analysis of variance using the SAS software, general linear model (SAS Institute, 2008). The main effects were line and sex. Traits analyzed were: LBW at hatch, 14 days, 28 days, and 42 days for Giza M2 and the RBC lines. The following model was used:

$\mathrm{Y}_{\mathrm{ijk}}=\mu+\mathrm{L}_{\mathrm{i}}+\mathrm{S}_{\mathrm{j}}+\mathrm{LS}_{\mathrm{ij}}+\mathrm{e}_{\mathrm{ijk}}$

Where:
$Y_{\mathrm{ijk}}$ : The $\mathrm{K}^{\text {th }}$ observation of the $\mathrm{j}^{\text {th }} \operatorname{sex}$ within the $i^{\text {th }}$ line.

$\mu$ : The overall mean.

$\mathrm{L}_{\mathrm{i}}$ : The effect of the $\mathrm{i}^{\text {th }}$ line.

$S_{j}$ : The effect of the $j^{\text {th }}$ sex

$\mathrm{LS}_{\mathrm{ij}}$ : The interaction between the $\mathrm{i}^{\text {th }}$ line and the $\mathrm{j}^{\text {th }}$ sex

$E_{\mathrm{ijk}}$ : Random error.

For the analysis of; ASM, BWSM, EN, EW and FEW during the first 36 weeks of age for Giza M-2and the RBC lines, data were analyzed as a one-way analysis of variance using the SAS software, general linear model (SAS Institute, 2008). The following model was used:

$\mathrm{Y}_{\mathrm{ij}}=\mu+\mathrm{L}_{\mathrm{i}}+\mathrm{e}_{\mathrm{ij}}$

Where:

$\mathrm{Y}_{\mathrm{ij}}$ : The $\mathrm{j}^{\text {th }}$ observation within the $\mathrm{i}^{\text {th }}$ line.

$\mu$ : The overall mean.

$\mathrm{L}_{\mathrm{i}}$ : The effect of the $\mathrm{i}^{\text {th }}$ line.

$\mathrm{E}_{\mathrm{ij}}$ : Random error.

All data are reported as least square means (LSM) \pm standard errors (SE). Mean values were separated, when significance existed, using Duncan's multiple range test (Duncan's, 1955). Significance level was set at $5 \%$.

\section{RESULTS AND DISCUSSION 1- Giza B-1line live body weight from hatch until 42 days}

2- For all generations, Giza M-2 line had significantly higher LBW at hatch, 14, 28, and 42 days of age in comparison to the RBC line as mixed sex. The average LBW of Giza M-2 and RBC lines by generation at 6 weeks of age were $862 \mathrm{~g}$ vs. $550 \mathrm{~g}$ (G3), and $983 \mathrm{~g}$ vs. $625 \mathrm{~g}$ (G5), respectively, with significant differences for both lines (Table 1).

3- Many approaches could be used to improve chicken lines for meat production; Chambers et al. (1981) reported on the efficiency of selection to improve broiler LBW. The difference between, two lines selected divergently for 
Broiler breeders, Body weight, Egg production, Selection, Sexual maturity.

7-week LBW, was approximately $800 \mathrm{~g}$ after ten generations of selection (Dunnington and Siegel, 1995). In our results the differences between Giza M-2 and $\mathrm{RBC}$ lines were $358 \mathrm{~g}$ after five generations of selection for high LBW at 6 weeks LBW.

Siegel (1978) indicated that high weight lines have shown a gain of $26 \mathrm{~g}$ and $20 \mathrm{~g}$ per generation for males and females, respectively, after 20 generations of selection. Also, Pollock (1999) demonstrated that, after 9 years of selection in chicken, broiler growth rate increased from $39 \mathrm{~g}$ to $44 \mathrm{~g}$ per day. However, in our study, and after 5 generations of selection, the daily growth, of Giza M-2 line, was about $22 \mathrm{~g}$ per day. This was in contrast to the RBC which was less than $14 \mathrm{~g}$ per day. This is an improvement of $8 \mathrm{~g}$ per day or about $57 \%$ over the RBC line (Table 1).

Schmidt et al. (2006) stated that, the LBW at 6 weeks of age for three broiler male lines (PP, VV and KK) which have been selected for meat production was $1906 \mathrm{~g}$, $1950 \mathrm{~g}$, and $1989 \mathrm{~g}$, respectively, in comparison to $1402 \mathrm{~g}$ for the control line after 15 generations of selection. In our study, Giza M-2 and the RBC lines weighted $983 \mathrm{~g}$ and $625 \mathrm{~g} \mathrm{LBW}$ at 6 weeks of age after 5 generations of selection (Table 1).

Our results indicated that for all generation, at all ages, Giza M-2 males had significantly higher LBW in comparison to the RBC line males (Table 2). In addition, Giza M-2 males had significantly $(\mathrm{P} \leq 0.05)$ higher $\mathrm{LBW}$ in comparison to the RBC males at hatch, 14 days, 28 days, and 42 days of age (Table 2). The average LBW of Giza M-2 males and RBC males lines, by generation, at 6 weeks of age were $888 \mathrm{~g}$ vs. $562 \mathrm{~g}$ (G3),
957 g vs. 599 (G4), 1019 g vs. 630 g (G5) respectively.

Our results indicated that, for all generation, at all ages, Giza M-2 females had significantly higher LBW in comparison to the RBC line females (Table 3).Giza M-2 females had significantly $(\mathrm{P} \leq 0.05)$ higher $\mathrm{LBW}$ in comparison to the RBC females at hatch, 14 days, 28 days, and 42 days of age (Table 3). The average LBW of Giza M-2 females and RBC females lines by generation at 6 weeks of age were $820 \mathrm{~g}$ vs. $537 \mathrm{~g}$ (G3), $876 \mathrm{~g}$ vs. $533 \mathrm{~g}$ (G4), and $924 \mathrm{~g}$ vs. 619. $\mathrm{g}(\mathrm{G} 5)$, respectively.

Growth rate, yield, feed conversion ratio, and egg production of broiler breeder lines have moderate heritability values (20 to $40 \%$ ) and showed more response to selection (Chambers, 1990). Also, Pakdel et al. (2005) stated that, divergent selection for LBW, the selection response for LBW of $130 \mathrm{~g}$ was observed. In this study, selection response in Giza M-2 line at 6 weeks LBW during the last four generation of selection, were $312 \mathrm{~g}, 336 \mathrm{~g}$, and $358 \mathrm{~g}$, as combined sex, respectively (Table. 1).

Mignon-Grasteau et al. (2000) stated that, the increase in sexual dimorphism, in LBW could be reduced by selecting animals based on LBW, as is usually done in commercial broiler lines. Giza M-2 females weighted, on the average, about $91 \%$ of their males' counterparts at 6 weeks of age. However, the RBC females weighted, on the average, about $98 \%$ of their males' counterparts. This would indicate that selection for increased 6week LBW increased the sexual dimorphism by almost $7 \%$ (Table 4). The percentage of the difference between the selected Giza M-2 line and the RBC line increased by the progress of selection (Table 4). These results disagree with the 
results previously reported by MignonGrasteau et al. (2000).

Schmidt et al. (2006) reported that selection for increased LBW in broiler breeders includes maternal effects which have positive association with the LBW of its progenies after hatch. In addition, Peeters et al. (2012) stated that individuals can affect one another's phenotype. The heritable effect of an individual on the phenotype of a conspecific individual is known as an indirect genetic effect (IGE). The IGEs can have a substantial impact on heritable variation and response to selection. Thus, for the IGEs, it mattered which pedigree line provided the sire and which provided the dam. They stated that indirect parent-of-origin effect appeared to be paternally transmitted and are probably $\mathrm{Z}$ chromosome linked.

Our data indicated that, Giza M-2 line had significant increases in its LBW for all ages studied, from one generation to the next, in comparison to the RBC line. This is due to selection for increased LBW at 6 weeks of age in Giza M-2 line from one generation to the next. These results are in agreement with the results previously reported by Schmidt et al. (2006). These results are also in agreement with the results previously reported by Peeters et al. (2012).

Tixier-Boichard et al. (2012) stated that continuous intensive selection, with focus on minimal marketable age, causes rapid progress, with mass selection, for a trait with moderately high heritability, based on early measurement of LBW in both sexes. Also, Rovadoscki et al. (2016) stated that genetic gain for body weight can be achieved by selection. Also, selection for body weight at 42 days of age can be maintained as a selection criterion. Continuous intensive selection with focus on 6-week LBW in Giza M-2 line that can be measured in both sexes before sexual maturity, resulted in increased LBW at 6 weeks of age, from generation to the next. These results are in agreement with those of Tixier-Boichard et al. (2012) and Rovadoscki et al. (2016).

\section{Correlated response: age and body weight at sexual maturity}

The relationship between LBW and reproduction is not a simple one in restricted-fed broiler breeder females because body composition plays a major role in the sexual maturation process (Bornstein et al., 1984). However, it is often assumed that high uniformity causes a reduction of variability in ASM and EW because LBW is considered a major determinant of both of those variables (Hocking, 2004). Maintaining a high LBW uniformity is a major objective during the rearing period in broiler breeder pullets to achieve optimum reproductive performance (Hocking, 2004).

Our results indicated that, Giza M-2 line had significantly higher body weight at sexual maturity (BWSM) for the last three generations in comparison to those of the RBC line (Table 5). This may be due to the selection for high LBW at 6 weeks of age in Giza M-2 line. A major objective of the genetic selection in Giza M-2 line has been to increase LBW at earlier ages and this strategy has changed LBW at different points along the growth curve that includes BWSM.

On the other hand, Giza M-2 line had significantly higher ASM in comparison to the RBC line in G3, G4, and G5. Also, Our results indicated that, increasing 6-week LBW in the female of Giza M-2line from one generation to the next, due to selection for high 6-week LBW resulted in an association increase in BWSM which led to an increase in the ASM of Giza M-2 line. In addition, there was an increase in 
Broiler breeders, Body weight, Egg production, Selection, Sexual maturity.

ASM of Giza M-2 line by one day from one generation to the next. These results are in agreement with the results previously reported by Spies et al. (2000) and Renema et al. (2007).

\section{Egg number and egg weight}

Genetic selection for growth and breast meat yield has resulted in the development of different commercial crosses designed to cover the various needs of the poultry markets. Because LBW and reproduction are negatively correlated, maximizing egg production while selecting for higher juvenile LBW becomes more complex with each generation of selection for growth and yield (Melnychuk et al., 2004; Luo et al., 2007).

Our results indicated that, Giza M-2 line had significantly $(\mathrm{P} \leq 0.05)$ higher $\mathrm{EN}$, FEW, and EW in comparison to the RBC line (Table 5). The EN of Giza M-2 and $\mathrm{RBC}$ lines for the first 36 weeks of age are presented in Table (5). The increase in EN, for Giza M-2 line, is due to our selection to increase EN (through independent culling level) in Giza M-2 line in all generations. In addition, Giza M-2 had significantly higher FEW in comparison to the RBC line (Table 5). Also, Giza M-2 line had higher EW during the first 36 weeks of age in comparison to the RBC line (Table 5).

Anthony et al. (1991) reported that a major objective of genetic selection, in commercial meat strains of poultry, has been to increase LBW at earlier ages and this strategy has changed LBW at different points along the growth curve. In addition, Romero et al. (2009) stated that genetic selection schemes used to change an animal's pattern of growth results in both short-term and long-term effects on other traits. These traits include organ and muscle accretion patterns, the onset of sexual maturity, and overall reproductive efficiency.

Our results indicated that genetic selection, in Giza M-2 line, changed the growth pattern and other traits such as LBW at hatch, 2, 4, and 6 weeks of age. It also affected the overall reproductive efficiency including FEW, EW, and EN in Giza M-2 line. These results are in agreement with the results previously reported by Anthony et al. (1991) and Romero et al. (2009).

Many studies had indicated that EW is usually positively correlated with hen weight (Spies et al., 2000; Renema et al., 2007; Romero et al., 2009). Since Giza M2 line is heavier LBW than the RBC in all generation, it also showed heavier FEW and EW during the first 36 weeks of age in the last three generation of selection. The differences in EW between Giza M-2 and the RBC lines was $3 \mathrm{~g}$ (G3) vs. $4 \mathrm{~g}$ (G5). Also, the differences in FEW between Giza M-2 and the RBC lines were $6 \mathrm{~g}$ (G3) vs. $7 \mathrm{~g}$ (G5). These results are in agreement with the results previously reported by Spies et al., (2000), Renema et al., (2007), and Romero et al., (2009).

\section{CONCLUSION}

Selection in broiler breeding has large impact on frequency of genes controlling economically important traits, such as weight gain, muscle mass, feed efficiency and reproduction ( $\mathrm{Fu}$ et al., 2016). Giza M-2 line was superior in body weight during the G3, G4, and G5 in comparison to the RBC line. Moreover, selection for LBW has contributed to the increases in productivity and efficiency obtained in this study. However, this improvement has negative effects on reproductive performance in the Giza M-2 line. If these improvements, in body weight, of the Giza M-2 line will continue at the same rate, we can expect that after several generations of 
Farid S. Nassar

selection, Giza M-2 line will be a local line with very good performance for meat production. In Giza M-2 line, future generations, to achieve proper meat production, we will focus on genetic selection of traits relevant to modern broiler breeding.

\section{ACKNOWLEDGEMENT}

The author is grateful to Dr. Mohamed A. Elshafei، Managing Director of Ismailia/Misr Poultry Company, Egypt, for fully supporting financially this research. 
Table (1): Live body weight (g) (LSM \pm SE) at different ages, from generation 3 (G3) to generation 5 (G5) for both Giza $\mathrm{M}-2$ and the RBC lines, as a straight run

\begin{tabular}{|c|c|c|c|c|c|}
\hline \multirow{2}{*}{ Generation } & \multirow{2}{*}{ Line } & \multicolumn{4}{|c|}{ Age } \\
\hline & & Hatch & 14 days & 28 days & 42 days \\
\hline \multirow[t]{2}{*}{ G3 } & Giza M-2 & $39.23 \pm 0.10^{b}$ & $230.12 \pm 1.23^{\mathrm{c}}$ & $469.62 \pm 2.34^{\mathrm{c}}$ & $862.72 \pm 4.15^{\mathrm{c}}$ \\
\hline & $\mathrm{RBC}$ & $35.85 \pm 0.10^{\mathrm{e}}$ & $132.72 \pm 1.23^{\mathrm{f}}$ & $268.83 \pm 2.34^{\mathrm{f}}$ & $550.43 \pm 4.15^{\mathrm{e}}$ \\
\hline \multirow[t]{2}{*}{ G4 } & Giza M-2 & $39.59 \pm 0.10^{\mathrm{a}}$ & $246.83 \pm 1.23^{\mathrm{b}}$ & $491.92 \pm 2.34^{\mathrm{b}}$ & $916.41 \pm 4.15^{b}$ \\
\hline & $\mathrm{RBC}$ & $36.49 \pm 0.10^{\mathrm{d}}$ & $137.62 \pm 1.23^{\mathrm{e}}$ & $296.67 \pm 2.34^{\mathrm{e}}$ & $580.32 \pm 4.15^{\mathrm{e}}$ \\
\hline \multirow[t]{2}{*}{ G5 } & Giza M-2 & $39.86 \pm 0.10^{\mathrm{a}}$ & $279.10 \pm 1.23^{\mathrm{a}}$ & $528.07 \pm 2.34^{\mathrm{a}}$ & $983.35 \pm 4.15^{\mathrm{a}}$ \\
\hline & RBC & $36.10 \pm 0.10^{c}$ & $155.41 \pm 1.23^{\mathrm{d}}$ & $353.04 \pm 2.34^{\mathrm{d}}$ & $625.18 \pm 4.15^{\mathrm{d}}$ \\
\hline
\end{tabular}

* Means, within age, with different superscripts are significantly different $(\mathrm{P} \leq 0.05)$.

Table (2): Live body weight (g) (LSM \pm SE) at different ages, from generation 3 (G3) to generation 5 (G5) for males of Giza M-2 and the RBC lines

\begin{tabular}{|c|c|l|l|l|l|}
\hline \multirow{2}{*}{ Generation } & \multirow{2}{*}{ Line } & \multicolumn{4}{|c|}{ Age } \\
\cline { 3 - 6 } & & Hatch & 14 days & 28 days & 42 days \\
\hline \multirow{2}{*}{ G3 } & Giza M-2 & $39.28 \pm 0.13^{\mathrm{b}}$ & $246.10 \pm 1.50^{\mathrm{c}}$ & $469.99 \pm 2.90^{\mathrm{c}}$ & $888.75 \pm 5.20^{\mathrm{c}}$ \\
& RBC & $36.25 \pm 0.14^{\mathrm{d}}$ & $138.98 \pm 1.65^{\mathrm{e}}$ & $277.99 \pm 3.18^{\mathrm{f}}$ & $562.27 \pm 5.69^{\mathrm{f}}$ \\
\multirow{2}{*}{ G4 } & Giza M-2 & $39.68 \pm 0.13^{\mathrm{a}}$ & $261.10 \pm 1.50^{\mathrm{b}}$ & $497.99 \pm 2.90^{\mathrm{b}}$ & $957.32 \pm 5.20^{\mathrm{b}}$ \\
& RBC & $36.56 \pm 0.14^{\mathrm{d}}$ & $143.00 \pm 1.65^{\mathrm{e}}$ & $302.99 \pm 3.18^{\mathrm{e}}$ & $599.96 \pm 5.69^{\mathrm{e}}$ \\
\multirow{2}{*}{ G5 } & Giza M-2 & $39.96 \pm 0.13^{\mathrm{a}}$ & $283.45 \pm 1.50^{\mathrm{a}}$ & $532.99 \pm 2.90^{\mathrm{a}}$ & $1019.10 \pm 5.20^{\mathrm{a}}$ \\
& RBC & $37.12 \pm 0.14^{\mathrm{c}}$ & $158.60 \pm 1.65^{\mathrm{d}}$ & $367.99 \pm 3.18^{\mathrm{d}}$ & $630.11 \pm 5.69^{\mathrm{d}}$ \\
\hline
\end{tabular}

* Means, within age, with different superscripts are significantly different $(\mathrm{P} \leq 0.05)$. 
Table (3): Live body weight $(\mathrm{g})(\mathrm{LSM} \pm \mathrm{SE})$ at different ages, from generation 3 (G3) to generation 5 (G5) for females of Giza M-2 and the RBC lines

\begin{tabular}{|c|c|c|c|c|c|}
\hline \multirow{2}{*}{ Generation } & \multirow{2}{*}{ Line } & \multicolumn{4}{|c|}{ Age } \\
\hline & & Hatch & 14 days & 28 days & 42 days \\
\hline \multirow[t]{2}{*}{ G3 } & Giza M-2 & $39.12 \pm 0.16^{\mathrm{b}}$ & $202.49 \pm 1.92^{\mathrm{c}}$ & $469.00 \pm 3.86^{\mathrm{c}}$ & $820.23 \pm 6.69^{c}$ \\
\hline & $\mathrm{RBC}$ & $35.39 \pm 0.14^{\mathrm{e}}$ & $125.82 \pm 1.70^{f}$ & $258.64 \pm 3.42^{f}$ & $537.49 \pm 5.93^{\mathrm{e}}$ \\
\hline \multirow[t]{2}{*}{ G4 } & Giza M-2 & $39.43 \pm 0.16^{\mathrm{ab}}$ & $222.00 \pm 1.92^{b}$ & $482.00 \pm 3.86^{\mathrm{b}}$ & $876.15 \pm 6.69^{b}$ \\
\hline & $\mathrm{RBC}$ & $36.42 \pm 0.14^{\mathrm{d}}$ & $132.90 \pm 1.70^{\mathrm{e}}$ & $289.89 \pm 3.42^{\mathrm{e}}$ & $533.49 \pm 5.93^{\mathrm{e}}$ \\
\hline \multirow[t]{2}{*}{ G5 } & Giza M-2 & $39.72 \pm 0.16^{\mathrm{a}}$ & $271.99 \pm 1.92^{\mathrm{a}}$ & $520.00 \pm 3.86^{\mathrm{a}}$ & $924.32 \pm 6.69^{a}$ \\
\hline & $\mathrm{RBC}$ & $36.98 \pm 0.14^{\mathrm{c}}$ & $151.99 \pm 1.70^{\mathrm{d}}$ & $336.99 \pm 3.42^{\mathrm{d}}$ & $619.43 \pm 5.93^{d}$ \\
\hline
\end{tabular}

* Means, within age, with different superscripts are significantly different $(\mathrm{P} \leq 0.05$ 
Table (4): Sexual dimorphism of Giza M-2 and the RBC lines from generation 3 (G3) to generation 5 (G5)

\begin{tabular}{|c|c|c|c|c|c|c|c|c|}
\hline \multirow{3}{*}{ Traits } & \multicolumn{4}{|c|}{ 6-week LBW (g) } & \multicolumn{2}{|c|}{$\begin{array}{c}\text { Differences } \\
\text { between sexes (g) }\end{array}$} & \multirow{3}{*}{$\begin{array}{l}\text { Difference } \\
\text { between } \\
\text { lines }\end{array}$} & \multirow{3}{*}{$\begin{array}{c}\text { \% Difference } \\
\text { between } \\
\text { lines }\end{array}$} \\
\hline & \multicolumn{2}{|c|}{ Giza M-2 } & \multicolumn{2}{|c|}{ RBC } & \multirow{2}{*}{$\begin{array}{l}\text { Giza } \\
\text { M-2 }\end{array}$} & \multirow{2}{*}{$\mathbf{R B C}$} & & \\
\hline & Male & Female & Male & Female & & & & \\
\hline G3 & 888 & 820 & 562 & 537 & 68 & 25 & 43 & 63.2 \\
\hline G4 & 957 & 876 & 599 & 533 & 81 & 26 & 55 & 67.9 \\
\hline G5 & 1019 & 924 & 630 & 619 & 95 & 11 & 84 & 88.4 \\
\hline
\end{tabular}

Table (5): Weight at sexual maturity, age at sexual maturity, egg number during the first 36-week of age, average egg weight for the eggs produced during the first 36 weeks of age, weight of first egg (LSM \pm SE) of Giza M-2 and the RBC lines in the generations studied

\begin{tabular}{|l|l|l|c|l|l|l|}
\hline & & & & \\
Traits & BWSM (g) & ASM (days) & EN** & EW (g)** & FEW (g) \\
\hline G3 & Giza M-2 & $2350 \pm 12.89^{\mathrm{b}}$ & $160 \pm 0.66^{\mathrm{a}}$ & $70 \pm 0.64^{\mathrm{a}}$ & $48 \pm 0.18^{\mathrm{c}}$ & $45 \pm 1.06^{\mathrm{a}}$ \\
& RBC & $2194 \pm 15.75^{\mathrm{d}}$ & $157 \pm 0.81^{\mathrm{b}}$ & $59 \pm 0.78^{\mathrm{b}}$ & $45 \pm 0.22^{\mathrm{e}}$ & $39 \pm 1.33^{\mathrm{b}}$ \\
G4 & Giza M-2 & $2404 \pm 12.89^{\mathrm{a}}$ & $160 \pm 0.66^{\mathrm{a}}$ & $69 \pm 0.64^{\mathrm{a}}$ & $49 \pm 0.16^{\mathrm{b}}$ & $45 \pm 1.06^{\mathrm{a}}$ \\
& RBC & $2230 \pm 15.75^{\mathrm{cd}}$ & $157 \pm 0.81^{\mathrm{b}}$ & $59 \pm 0.78^{\mathrm{b}}$ & $45 \pm 0.22^{\mathrm{e}}$ & $39 \pm 1.33^{\mathrm{b}}$ \\
& Giza M-2 & $2435 \pm 12.89^{\mathrm{a}}$ & $161 \pm 0.66^{\mathrm{a}}$ & $69 \pm 0.64^{\mathrm{a}}$ & $50 \pm 0.16^{\mathrm{a}}$ & $46 \pm 1.06^{\mathrm{a}}$ \\
& RBC & $2252 \pm 15.75^{\mathrm{c}}$ & $157 \pm 0.81^{\mathrm{b}}$ & $61 \pm 0.78^{\mathrm{b}}$ & $46 \pm 0.22^{\mathrm{d}}$ & $39 \pm 1.33^{\mathrm{b}}$ \\
\hline
\end{tabular}

BWSM= body weight at sexual maturity, $\mathrm{ASM}=$ age at sexual maturity, $\mathrm{EN}=$ egg number, $\mathrm{EW}=$ egg weight, $\mathrm{FEW}=$ weight of first egg.* Means within traits, with different superscripts are significantly different $(\mathrm{P} \leq 0.05)$.

$* *$ During the first 36 weeks of age. 


\section{REFERENCES}

Alnahhas, N.; Berri, C.; Chabault, M.; Chartrin P.; Boulay, M.; and Bourin M. C., 2016. Genetic parameters of white striping in relation to body weight, carcass composition, and meat quality traits in two broiler lines divergently selected for the ultimate $\mathrm{pH}$ of the pectoralis major muscle. BMC Genetics, 17:61-69.

Anthony, N. B.; Emmerson, D. A.; Nestor, and K. E., 1991. Genetics of growth and reproduction in the turkey. 12. Results of long-term selection for increased 180-day egg production. Poult. Sci., 70:1314-1322.

Baéza, E.; Arnould, C.; Jlali M.; Chartrin, P.; Gigaud, V.; Mercerand, F.; Durand, C.; Méteau, K. E.; Le Bihan-Duval, E.; and Berri, C., 2012. Influence of increasing slaughter age of chickens on meat quality, welfare, and technical and economic results. J. Anim. Sci., 90:2003-2013.

Bornstein, S.; Plavnik, I.; and Lev, Y., 1984. Body weight and / or fatness as potential determinants of the onset of egg production in broiler breeder hens. Br. Poult. Sci., 25: 323 - 341.

Chambers, J. R., 1990. Genetics of growth and meat production in chickens. In: Poultry Breeding and Genetics, (Ed. Crawford, R. D.), Elsevier Science Publishing Co., New York, USA, pp. 599-643.

Chambers, J. R.; Gavora, J. S.; and Fortin, A., 1981. Genetic changes in meat-type chickens in the last twenty years. Canad. J. of Anim. Sci., 61:555563.

Decuypere, E.; Bruggeman, V.; Barbato, G. F.; and Buyse, J., 2003. Growth and reproduction problems associated with selection for increased broiler meat production. In: Poultry Genetics, Breeding and Biotechnology, (Eds. Muir, W. M. and Aggrey, S. E.), CABI Publ., Cambridge, MA 02138, USA, pp.13-28.

Duncan, D. B., 1955. Multiple range and multiple F test. Biometrics, 11: 1-42.

Dunnington, E. A.; and Siegel P. B., 1995. Enzyme activity and organ development in newly hatched chicks selected for high or low eight-week body weight. Poult. Sci., 74:761-770.

FAO. World agriculture towards 2030/2050, The 2012 Revision. In: FAO: Agricultural Development Economics Division. 2012. Available at: $\mathrm{http} / /$ : www.fao.org/docrep/016/ap106e/ap10 6e.pdf.

Fu, W.; Lee, W. R; and Abasht, B., 2016. Detection of genomic signatures of recent selection in commercial broiler chickens. BMC Genetics, 17:122-132

Hocking, P. M., 2004. Roles of body weight and feed intake in ovarian follicular dynamics in broiler breeders at the onset of lay and after a forced molt. Poult. Sci., 83: $2044-2050$.

Hunton, P., 2006. 100 years of poultry genetics. Worlds Poult. Sci. J. 62:417428.

Luo, P. T.; Yang, R. Q.; and Yang, N., 2007. Estimation of genetic parameters for cumulative egg numbers in a broiler dam line by using a random regression model. Poult. Sci., 86: 30-36.

Melnychuk, V. L.; Kirby, J. D.; Kirby, Y. K.; Emmerson, D. A.; and Anthony, N. B., 2004. Effect of strain, feed allocation program, and age at photostimulation on reproductive development and carcass 
Broiler breeders, Body weight, Egg production, Selection, Sexual maturity.

characteristics of broiler breeder hens. Poult. Sci., 83:1861-1867.

Mignon-Grasteau, S.; Piles, M.; Varona, L.; de Rochambeau, H.; Poivey, J. P.; Blasco, A.; and Beaumont, C., 2000. Genetic analysis of growth curve parameters for male and female chickens resulting from selection on shape of growth curve. J. of Anim. Sci., 78:2515-2524.

Muir, W. M.; Wong, G. K.; Zhang, Y.; Wang, J.; Groenen, M. A. M.; Crooijmans, R. P. M. A.; Megens, H. J.; Zhang, H.; Okimoto, R.; Vereijken, A.; Jungerius, A.; Albers, G. A. A.; Lawley, C. T.; Delany, M. E.; MacEachern, S.; Cheng, H. H., 2008. Genome-wide assessment of worldwide chicken SNP genetic diversity indicates significant absence of rare alleles in commercial breeds. Proceedings of the National Academy of Science, USA, 105:17312-17317.

Nassar, F. S.; Moghaieb, R. E. A.; Abdou, A. M.; and Stino. F. K. R., 2012. Microsatellite markers associated with body and carcass weights in broiler breeders. Afr. J. Biotech., 11:3514-3521.

Pakdel, A.; Bijma, P.; Ducro, B. J.; and Bovenhuis, H., 2005. Selection strategies for body weight and reduced ascites susceptibility in broilers. Poult. Sci., 84:528-535.

Peeters, K.; Eppink, T. T.; Ellen, E. D.; Visscher, J.; and Bijma, P. 2012. Indirect genetic effects for survival in domestic chickens (Gallus gallus) are magnified in crossbred genotypes and show a parent-of-origin effect. Genetics, 192: 705-713.

Petracci, M.; and Cavani, C., 2012. Muscle growth and poultry meat quality issues. Nutr. 4:1-12.
Pollock, D. L., 1999. A geneticist's perspective from within a broiler primary breeder company. Poult. Sci., 78: 414-418.

Renema, R. A.; Robinson, F. E.; and Zuidhof, M. J., 2007. Reproductive efficiency and metabolism of female broiler breeders as affected by genotype, feed allocation, and age at photostimulation. 2. Sexual maturation. Poult. Sci., 86:2267-2277.

Romero, L. F.; Zuidhof, M. J.; Renema, R. A.; Naeima, A.; Robinson, F. E., 2009. Characterization of energetic efficiency in adult broiler breeder hens. Poult. Sci., 88:227-235.

Rovadoscki, G. A.; Petrini, J.; RamirezDiaz, J.; Pertile, S. F. N.; Pertille, F.; Salvian, M.; Iung, L. H. S.; Rodriguez, M. A. P.; Zampar, A.; Gaya, L. G.; Carvalho, R. S. B.; Coelho, A. A. D.; Savino, V. J. M.; Coutinho, L. L., and Mour̃ao, G. B. 2016. Genetic parameters for growth characteristics of free-range chickens under univariate random regression models. Poult. Sci. 95:1989-1998.

SAS Institute, 2008. Statistical analysis systems user's guide," Version 9.2. SAS Inst., Inc., Cary, NC. USA. 170 pp.

Schmidt, G.S.; Figueiredo, E. A. P.; Ledur, M.C., 2006. Genetic gain for body weight, feed conversion and carcass traits in selected broiler strains. Brazil. J. of Poult. Sci., 8:29 - 32.

Siegel, P. B., 1978. Response to twenty generation of selection for body weight in chickens. In: Proceedings of the 16th World's Poultry Congresss, Rio de Janeiro, Brazil, p.1761-1772.

Siegel, P. B.; and Dunnington, E. A., 1985. Reproductive complications associated with selection for broiler growth. Br. Poult. Sci., 26:59-72. 
Spies, A. A. B.; Robinson, F. E.; Renema, R. A.; Feddes, J. J. R.; Zuidhof, M. J.; Fitzsimmons, R. C., 2000. The Effects of body weight and long ahemeral days on early production parameters and morphological characteristics of broiler breeder hens. Poult..

Stainton, J.J.; Charlesworth, B.; Haley, C.S.; Kranis1, A.; Watson, K., and Wiener, P. 2017. Use of high-density SNP data to identify patterns of diversity and signatures of selection in broiler chickens. J. Anim. Breed. Genet., 134: 87-97.

Tixier-Boichard, M.; Leenstra, F.; Flock, D. K.; Hocking, P. M.; Weigend, S., 2012. A century of poultry genetics. World's Poult. Sci. J., 68: 307-321.

Wolanski, N. J.; Renema, R. A.; Robinson, F. E.; Carney, V. L.; Fancher, B. I., 2006. Relationship between chick conformation and quality measures with early growth traits in males of eight selected pure or commercial broiler breeder strains. Poult. Sci., 85:1490-1 
Broiler breeders, Body weight, Egg production, Selection, Sexual maturity.

$$
\begin{aligned}
& \text { الكفاءة الإتتاجية فى الاجاج المحلى بعد خمس أجيال من الخلط والإنتخاب لزيادة وزن }
\end{aligned}
$$

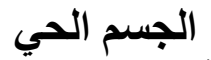

$$
\begin{aligned}
& \text { فريد صابر نصار الحير } \\
& \text { قسم الإنتاج الحيو انى ـ كلية الزر اعة - جامعة القاهرة ـ الجيزة } 12613 \text { - جمهورية مصر العربية }
\end{aligned}
$$

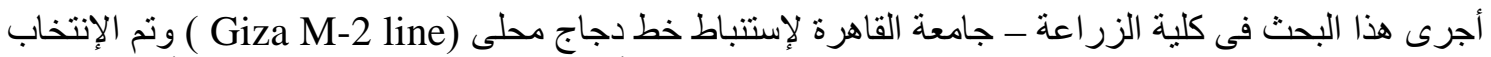

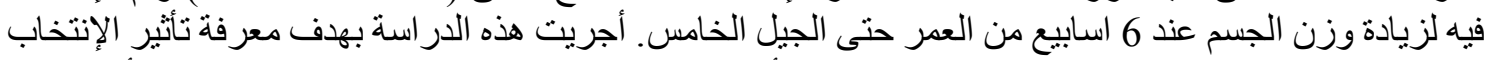

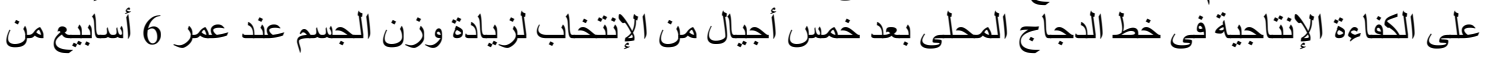

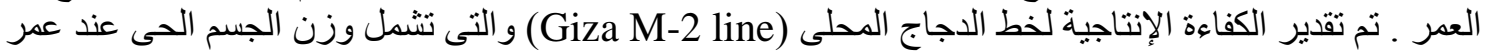

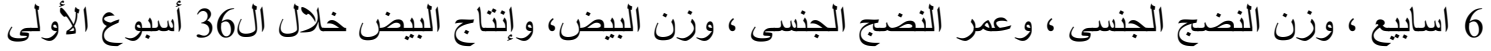
من العمر ومقارنتها بالمجمو عة الكونترول التى يتم إستخدامها خلال الجيل الثنالئ ولثالث و الر ابع و الخامس من الإنتخاب.

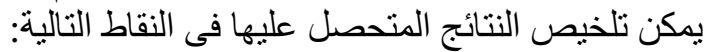

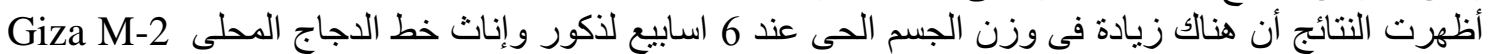
(line)

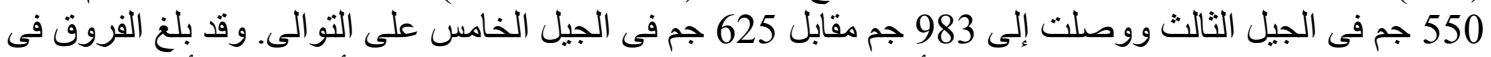

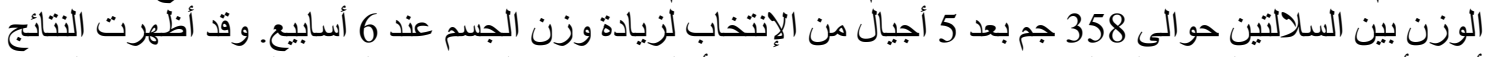

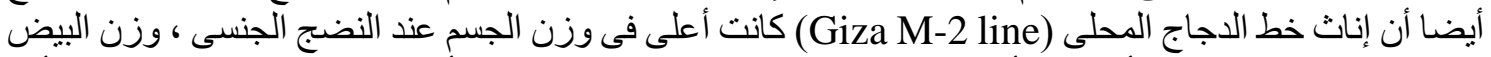

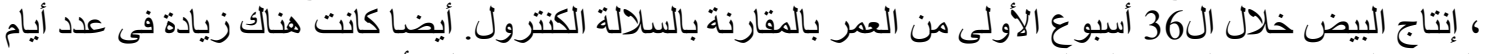

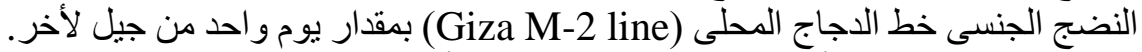

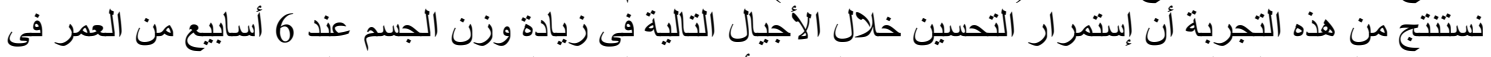

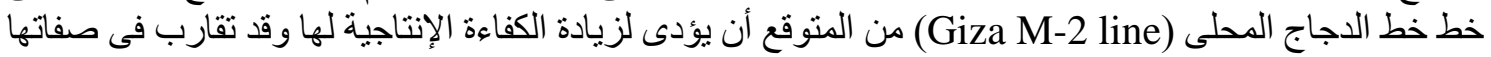
الإنتاجية للسلالات التجاريه. 